\title{
Developing Students' Participation in a Mixed-levels Reading Class via Cooperative Integrated Reading and Composition (CIRC)
}

\author{
Endang Sulistianingsih \\ Universitas Pancasakti Tegal \\ endang.sulistia@gmail.com
}

\begin{abstract}
Students, especially at the higher level need to bean efficient reader to comprehend somereading materials from varied sources associated with their studies. Teaching reading becomes not easy sincethe teacher has to face the problems on how to teach reading in a mixed-levelsreading class? How can all students become motivated more active in reading class? How to promote cooperation among students with divergent competency and motivation? To address such questions, this paper demonstrates how reading skill, participation, and cooperation can be developed through CIRC. The research was a case study where quantitative and qualitative were mixed. The participants of this research were students of communication studies at the Social and Political Science Faculty in higher education. Eighteen students participated in this research. The participant was took using saturation sampling. The data was collected through observation to determine students' participation and reading comprehension test to measure the student's reading comprehension level.CIRCwas used as teaching instruction during the intervention. Through this method, learning reading can increase good interrelationship, individual and group responsibility, interpersonal and small group skills. Therefore, a presence of cooperation is established, comprehension can be developed, and passive students become active while active students become active. This research is useful for EFL teacher who teaches in a big class where his/her studentshave different levels of reading proficiency.
\end{abstract}

\section{ARTICLE HISTORY}

Received 2 February 2018

Accepted 27 August 2018

\section{KEYWORDS}

Cooperative learning; reading comprehension; participation; colaborative reading; higher education

\section{Introduction}

In a country where reading is taught as a foreign language such as Indonesia, reading plays an important thing for students. Students require efficient reading ability to grasp a large scale of reading materials from varied sources related to their studies. This implies teaching reading is essential for it will be useful to make the students ready to have efficient reading skill in order to be able to acquire information and knowledge from any reading text. With sufficient reading ability, students are expected to develop their knowledge of the specific context given to them to learn. 
They are also intended to be able to extract the meaning of certain ideas in the text, get the essence of it, and gain certain information from reading the text.

Based on the observation done by the researcher she finds that her students are in different levels of reading proficiency. She teaches English for Special Purposes in higher education level. She reveals that some of her student's background of English knowledge is very poor while the others are in the middle and the rest isvery good. The poor ones cannot catch up with others in the class. And they become passive and hopeless in class activities - the students who have good English knowledge background, then very active in the class. Consequently, the condition fosters competition among the good students and discourages the poor students. Also, the poor students start to have a negative attitude towards studying English even though they know the importance of English.

Using Cooperative learning, students will be able to gain knowledge and establish interpersonal as well as team skills (Johnson and Johnson 1999). The problems faced by the classes which consist of good students and poor students would be resolved by this method because of its effectiveness. Students are asked to make the team from two or more different reading levels (Slavin 2011). This is one of the reasons why this method should be applied because it can easily manage the big class which has various needs of the mixed-level students. Another problem faced by the students is that they do not understand how to comprehend difficult texts where they do not know the meaning of the words. Moreover they found that they have a shortage of background knowledge. They do not know how to work through their reading difficulties to get the full meaning from reading texts. They become more frustrated since they may not know how to administer an appropriate method to improve their reading comprehension. Moreover, their teacher's method in traditionally way (usually Grammar Translation Method) make them get bored and frustrated in learning reading comprehension.

Hopefully, CIRC can solve the students' problems. This is because of some activities in cooperative learning are students learning together in a team on a series of activities involving cognition, outlining the stories together, and training spelling, decoding, and vocabulary. Students alsostudywith their teams to gain comprehension skills. And usually, students help their friends to grasp difficult ideas to one another through interpreting the teacher's language into their language. Also, poor students will take advantage from establishing cooperation with their friends who have a good achievement, and good students will feel content that they contribute to their poorer classmate achievement.

In conclusion, by implementing CIRC, the students hopefully are getting more interested in reading,and it will encourage the students to a condition that would require them to take the responsibility not only on their mastery but also their friends' understanding. Furthermore, the students will have higher achievement in 
reading and more positive relationships. In this study, the setting of the research is carried out in an EFL setting where the student's reading proficiency is mixed.

The aims of the study are: (1) To describe teaching reading in a mixed-levels reading class, (2) To describe motivating students' participation in class and (3) To describe promoting cooperation among students with divergent competency and motivation. It is hoped that this empirical study can provide guidelines for EFL teachers who wish to implement CIRC to enhance their students' language learning especially in reading competence as well as the development of motivation towards learning English as a foreign language. By carrying out this study, the researcher hopes CIRC can get more attention and leading popularity among EFL teachers at all grade levels. And this study can be used as an additional reference, especially those who are doing a similar study at reading comprehension.

\section{Review of Literature}

\section{Reading Comprehension}

Reading is a perpetual process of predicting, and what one carry to the text is often more prominent than what one finds in it (Swaffar 1985). Thus the students should be taught to use what they know to understand not familiar thingsif these are concepts or simple words. Comprehension occurs as the reader builds a psychological illustration of a text message. The comprehension activity happens at multiple levelsoverelements of language: word level (lexical processes), sentence level (syntactic processes), and text level. There are two maincategoriesof comprehension activities: (1) pinpointing of words, and (2) The involvement of the language processing mechanisms that make these words into messages (Perfetti and Hart 2001). These words give contextually convenient word meanings, parsing the word into its compiler, and give inferential integration of sentence information into more complete descriptions of comprehensive text.In the reading activity, the readers usually found themselves in a difficult situation where they can't comprehend the text well.

Chard, Stoolmiller et al. (2008) suggested that there are five specific reasons related to most reading comprehension matters are: (1) language procrastinates and difficulties; some students enter school with difficulties understanding spoken language that making slacken in their language construction, or second language learning. As a result, they are also facing difficulties understanding written language, (2) less in words awareness (3) lack of proper strategies; great readers use strategies before, during, and after reading that support them comprehend text. (4) Hardship comprehending text structures; when students do not know text structure scheme, then they have difficulty comprehending what was read and producing inferences. 


\section{Student's Participation in Reading}

Participation has been defined differently in many kinds of literature. Petress (2008)defines class participation includes three appraisingstandards: quantity, persistence, and quality. He pinpointsusualdiverting classroom behaviours and choices: pleonasticpresents (answers, questions, and promoting uttering for classmates require to be succinct, particular and pertinent), reiterantperceptions (students should be considerate), and reaction that disappoint others from contributing (indicated by verbally and nonverbally signs of impatience, boredom or superiority).

Some expertsdefinestudents' participation comprises ask questions, raise one's hand, and giving comments(Burchfield and Sappington 1999, Rocca 2010). Dancer and Kamvounias (2005)define participation as an active commitment action which can be sorted into five categories: arrangement, presenting to the discussion, group skills, communication skills, and attendance. (Wade 1994)Proposes that the ideal class discussion as the class where most of the students participate and are fascinated, learning, and listening to others' comments and suggestions.Green (2008)defines class participation as the action involved in the class. This involvement is outlined by the students in two ways: an active interference by giving opinions, answering questions, making comments, talking about a topic, participating in group discussion, reading and asking questions, showing interest, following classes with attention, and listening to others.

I suggest to redefining and rethinking what participation is meant. In this research, participation can be referred to the student's activeness and willingness to perform and to exist in the teaching-learning process. Students' activeness means that they provide either spontaneous or unsolicited contribution, such as giving the opinion, answering questions, and making comments — students' willingness to perform means that the student wills to read a text or retell the story without being asked or motivated again and again by the teacher. And exist in a teaching-learning process here means that student follows classes with attention and listening to others. In this research the students' participation is divided into two categories, they are active and passive students.

\section{Cooperative Integrated Reading and Composition (CIRC)}

The important things that exist in cooperative learning are group goals, individual accountability, and equal opportunity for success (Slavin, Hurley,et al. 2003). Group goals are important to support students to help each other to learn by giving them support in one another's success. Individual responsibility means that each member of the group is responsible for every task given to the group. Slavin (1990)says that everyone has the contribution to the group success. Cooperative Integrated Reading 
and Composition (CIRC) is one of the methods of cooperative learning approach that assists students to develop English language skills of the students.

The students may or may not use reading groups, as in traditional reading classes. Students are assigned to teams composed of pairs of students from two or more different reading levels. Students work in pairs within their teams on a series of cognitively engaging activities, including reading to one another, making predictions, summarizing, writing responses to stories, and practicing spelling, decoding, and vocabulary. Students also work in their teams to master the main idea and other comprehension skills. During language arts periods, students engage in a writer's workshop, writing a draft, revising and editing one another's works, and repairing for publication of team or class books.

In most CIRC activities students take a series of teacher instruction, team rehearsal, team pre-assessments, and quiz. Students do not do the quiz until their teammates have recommended that they are ready. Team rewards and certificates are given to team based on the average achievement of all team members on all reading and writing activities. Because students work on proper material to their reading levels, they have the samechance for success. Students' improvement to their team is based on the quiz scores which ensure individual responsibility.

\section{Research Method}

This research was a case study where quantitative and qualitative were mixed to meet the purpose of the research. In collecting the data, the researcher had to use an instrument, and they were observed and tested. The observation was used to determine the student's participation whether he/she is active or passive in reading classroom activities. The test was used to determine students' reading comprehension level. The population was also the sample; they were students of Communication Studies at Social and Political Science Faculty of Universitas Pancasakti Tegal. The total numbers of students were 18. The students were in the first semester when the research was conducted.

The observation was conducted before the treatment. In this study, I observed the students while I taught them. The form of observation also used non-systemic observation, in which I non-systematically observed the classroom un-announced, my students, that they were being observed. I was observing my students while teaching them. I noted the ways students participated as they learn and discussion in the class. Also, I used the attendance lists to keep track the student's name so I could record each of student's participation. The students were asked to state their name before making their comment so that participation could be accurately recorded. Here the researcher divided student's participation in reading class activities into active students and passive students. To determine the students' participation, I gave 
three aspects quoted from Green (2008) with some adaptation to meet the purpose of the research.

A student was considered active if she/he showed at least two of the following aspects observed:

(1) Willingness to perform in the classroom activity,

(2) Activeness in the classroom activity,

(3) The existence of the teaching-learning process.

A student was considered willing to perform in the classroom activities by reading or retelling the story without being asked or motivated again and again by the teacher.

A student was considered active in the classroom activities if he/she showed one of the following:

(a) Giving opinion

(b) Answering questions

(c) Making comments

(Adapted from Green, 2008)

A student was considered to exist in teaching learning process if he/she showed:

(a) Following classes with attention

(b) Listening to others

(Adapted from Green, 2008)

A student was consideredthey exist in teaching learning process if she/he paid attention and listen carefully when her/his teacher was teaching, and it was also when his/her friend was making comments, giving the opinion and answering questions. A student who played his/her gadget; for example, tab, phone cell, looked outside through the windows, had a daydreaming, fell asleep on the desk, did the task from another subject except for English while her/his teacher was teaching would not be considered to exist in the class.

To determine the reading comprehension of the students, the instrument used was IELTS reading. I used the same instrument for the pre-test and post-test. This was because the writer considered that the students wouldn't remember the passages.

\section{Result and Discussion}

During the first week, I carried out an observation to know the student's participation in reading class activities. After that, the rest of the time was used to assign the experimental students into groups and to explain CIRC activities. In this case, the students were assigned to five-member heterogeneous teams. Each team was made of a student of high ability, a student of lower ability, and two students of average abilities. In the next meeting, the researcher conducted the pre-test before starting teaching using CIRC. On the second to the fifth week, the students got the treatment. At the end of this study, the researcher administered the post-test. 
The researcher determined the student's participation in reading class activities by observing how the students participated in reading class activities. The researcher non-systematically observed the classroom while teaching and un-announced the students while she was observing the ways students participated as they learned and beginning taking notes on participation sheet. The students were categorized into active students and passive students. The students were categorized into active students were those who actively participated in reading class participation, while passive students were those who passively participated in reading class activities. The following was the summary of the observation result.

Table. 1Descriptive Statistics of Students' Participation

\begin{tabular}{ccc}
\hline Participation & Number of Students (percentage) / Student's Achievement \\
\cline { 2 - 3 } & Before Treatment & After Treatment \\
\hline Active & $5(28)$ & $14(78)$ \\
\hline Passive & $13(72)$ & $4(22)$ \\
\hline Total & $18(100)$ & $18(100)$ \\
\hline
\end{tabular}

Table 1 showed that 5 of the subjects were active learners $28 \%$ before CIRC method were implemented, and the rest 13 subjects were passive (72\%). After the CIRC method was implemented then the numbers of active students were raised. There were 14 active students (78\%) and then the numbers of passive students were 4 or $22 \%$. It means that CIRC could develop the students' participation in mixed levels reading class. Below is the diagram of students' participation development.

Table 1 revealed that the students' participation was developed.Most students become motivated more active in reading class since CIRC was employed. The students were willing to read or retell the story without being asked or motivated again and again by the teacher. The numbers of students who gave an opinion, answering questions and making comments in a teaching-learning process also increased. Most of the students paid attention and listened carefully when their teacher was teaching and when their friend was making comments, giving an opinion and answering questions. The numbers of students who played their gadget; for example tab, phone cell, looked outside through the windows, had a daydreaming, fell asleep on the desk, did the task from another subject except forEnglish whiletheir teacher was teaching were decreased.

Before being taught using CIRC method, the mean score of the whole students was 55 and after being taught was 80 . There was an increaseof $68 \%$ in students' reading comprehension achievement before and after the intervention. In CIRC activities, students worked in heterogeneous learning teams. Several studies had found that when students work together to accomplish a group goal, they come to express norms in favor of doing whatever was necessary for the group to succeed. 
Here, in this case, the active students made some efforts to achieve the team goals. It was found that students in cooperative groups who gained in achievement improved their social status in the classroom, whereas in the traditional classes such students lost status. It was an honor for the active students who had good achievement in reading comprehension to help their poorer classmates, and this was another reason why CIRC could develop active students' reading comprehension and made the active students became more active.Also, team rewards and certificates were given to team based on the average performance of all team members on all reading activities; this leads the active students to be well motivated to learn harder so that they could be a good achiever in reading comprehension. And they were pleased to help their poorer classmates especially those who were in the same group with them so that their team could get the reward, and it means that CIRC is successful in developing students' cooperation.

CIRC can develop passive students' reading comprehension since motivational perspectives on cooperative learning focused primarily on the reward or goal structures under which students operate. The passive students who did not have activeness and willingness to perform and existed in teaching learning process ofcourse would change their behavior to be active in classroom participation since they would seek ways so that the group was successful.

\section{Conclusion}

Cooperative Integrated Reading and Composition method, when employed at learning reading in mixed levels reading ability, can increase positive interdependence, individual and group accountability, face-to-face promotive interaction, interpersonal and small group skills, and group processing.

What should be emphasized is the teacher'sappearanceis very important in employing CIRC. To have an effective CIRC group, the teacher has to notice their students well. Grouping of students can be a difficult action and shouldbe considered with concern. Teachers must deal with the different learning skills, cultural background, personalities, and even gender when arranging the groups.

Also, the teacher must continue to provide instruction, monitor student's activity, and promote positive socialization. The teacher' instruction must help students to reach the specific cognitive goals associated with lessons to enhance group discussion; also, the teacher's instruction must deal with cognitive and metacognitive strategies. Moreover, Johnson and Johnson (1986) postulated five teacher roles in structuring cooperative learning strategies as follow: (1) teachers must determine the objectives for the lesson, (2) they must distribute students in learning groups before the class is started, (3) teachers shouldreveal the task and goal structure to the students, (4) teachers must monitor groups during cooperative learning and intervene to assist students when they need assistance to improve interpersonally and group skills, (5) teachers must evaluate the achievement of the students and provide the evaluation to them.

Thus, much time should be dedicated to adapt the lesson for CIRC. Teachers should vanish into the background and become a coach, facilitator, or and sometimes a spectator after the lesson is completed. Teachers who assemble a good cooperative lesson teach children to teach themselves and each other. Students learn from their peers and become less dependent on the teacher's assistance. 
9 | VISION: JOURNAL FOR LANGUAGE AND FOREIGN LANGUAGE LEARNING

Therefore, the presence of cooperation is established, reading and writing can be developed integrated, and passive students become active while active students become more active. 


\section{References}

Burchfield, C. M. and J. Sappington (1999). "Participation in Classroom Discussion." Teaching of Psychology

Chard, D. J., et al. (2008). "Predicting Reading Success in a Multilevel Schoolwide Reading Model: A Retrospective Analysis." Journal of Learning Disabilities41(2): 174-188

Dancer, D. and P. Kamvounias (2005). "Student Involvement in Assessment: A Project Designed to Assess Class Participation Fairly and Reliably." Assessment \& Evaluation in Higher Education 30(4): 445-454

Green, D. (2008). "Class Participation in a Teacher Training College: What is It and What Factors Influence It." English Language Teacher Education and Development11: 15-26

Johnson, D. W. and R. T. Johnson (1999). "Making Cooperative Learning Work." Theory into Practice38(2): 67-73

Perfetti, C. A. and L. Hart (2001). "The lexical Basis of Comprehension Skill."

Petress, K. (2008). "What is Meant by Active Learning?"." Education 128(4): 566570

Rocca, K. A. (2010). "Student Participation in The College Classroom: An Extended Multidisciplinary Literature Review." Communication Education 59(2): 185213

Slavin, R. (2011). "Cooperative learning." Learning and Cognition in Education: $160-166$

Slavin, R. E. (1990). Cooperative Learning: Theory, Research, and Practice, Prentice-Hall

Slavin, R. E., et al. (2003). "Cooperative Learning and Achievement: Theory and Research." Handbook of Psychology

Swaffar, J. K. (1985). "Reading Authentic Texts in a Foreign Language: A Cognitive Model." The Modern Language Journal69(1): 15-34

Wade, R. C. (1994). "Teacher Education Students' Views on Class Discussion: Implications for Fostering Critical Reflection." Teaching and Teacher Education 10(2): 231-243. 